\title{
The Development of Interpretataion Method For Remote Sensing Imagery In Determining The Candidate of Landslide In Leitimur Paninsula, Ambon Island
}

\author{
Ferad Puturuhu1, Projo Danoedoro², Junun Sartohadi², Danang Srihadmoko² \\ 1Doctoral Program in Geography, Universitas Gadjah Mada, Email: feradputuruhu@gmail.com \\ ${ }^{2}$ Geography Faculty Gadjah Mada University
}

\begin{abstract}
ABSTRAK
Penginderaa jauh merupakan salah satu metode yang digunakan untuk menjawab permasalahan penelitian tentang teknologi perolehan data spasial dan sekaligus permasalahan kewilayahan serta manajemen sumber daya laha. Pemanfaatan metode penginderaan jauh untuk penelitian landslide dianataranya metode interpretasi citra secara visual dan digital. Tujuan penelitian ini adalah membandingkan akurasi metode interpretasi dan menentukan lokasi kejadian landslide. Citra yang digunakan dalam penelitian ini adalah citra Landsat 8, Quickbird dan SRTM. Metode yang digunakan untuk menentukan kandidat landslide adalah interpretasi visual berlapis, Interpretasi citra digital dengan NDVI, OBIA, Toposhape, dan kombinasi NDVI-OBIA, dan NDVI-OBIA-Toposhape. Penggunaan metode interpretasi kejadian landslide yang terbaik adalah interpretasi visual berlapis dengan presentase $90 \%$. Interpretasi digital dengan NDVI mempunyai ketelitian $47 \%$, OBIA ketelitiannya $45 \%$, Toposhape $47 \%$, kombinasi NDVI-OBIA $47 \%$, dan Kombinasi NDVI-OBIA-Toposhape $53 \%$. Dari interpretasi visual berlapis dan pengamatan lapangan diperoleh tipe landslide yang ditemukan yaitu nendatan/slump (soil rotational slide) dalam jumlah yang banyak 7 titik (38.9\%), rayapan tanah (soil creep), aliran bahan rombakan (debris flow), longsor translasi dengan material tanah (earths Slide), dan nendatan majemuk (multiple rotational slide).
\end{abstract}

Kata kunci: Pengembanga, Metode, Interpretasi Citra, Penginderaan Jauh, Kandidat, Landslide, Paninsula Leitimur

\begin{abstract}
Remote sensing is one of the methods used to address the problem of research on spatial data acquisition technologies and is also acquiring the problems of territorial and land resource management. The utilization of remote sensing method for the landslide research is visual and digital imagery interpretation. The purpose of this study was to compare the accuracy of the method of interpretation and determine the location of the landslide event. The imagery that used in this study was Landsat 8, Quickbird and SRTM. The method that used to determine the candidate of landslide was the layered visual interpretation, digital imagery interpretation with NDVI, OBIA, Toposhape, and combination-OBIA NDVI and NDVI-OBIA-Toposhape. The use of the interpretation method for the landslide event is the best of layered-visual interpretation with a percentage of $90 \%$. Digital interpretation with NDVI has a $47 \%$ of its accuracy, thoroughness OBIA 45\%, Toposhape $47 \%$, the combination of NDVI-OBIA $47 \%$, and the combination of NDVI-OBIA-Toposhape 53\%. From the layered-visual interpretation and field observations were obtained type of landslide found that soil rotational slide in large quantities 7 points (38.9\%), creep soil (soil creep), the flow of material destruction (debris flow), landslides translation with soil materials (earths slide) and multiple rotational slide.
\end{abstract}

Keywords: Development, Method, Imagery Interpretation, Remote Sensing, Candidate of Landslide, Landslide and Leitimur Jaizirah

Citation: Puturuhu, F., Danoedoro, P., Sartohadi, J. and Srihadmoko, D. (2017). The Development of Interpretataion Method for Remote Sensing Imagery In Determining The Candidate of Landslide In Leitimur Paninsula, Ambon Island. Jurnal Ilmu Lingkungan, 15(1), 20-34, doi:10.14710/jil.15.1.20-34

\section{Introduction}

Remote sensing method is one of the means used to answer the problem of research on spatial data acquisition technology and at the same territorial issues (Suharyadi, 2008). It is also important in the management of land resources in the form of monitoring and mapping of the affected areas in a short recharge period (Sutanto, 1994), monitoring the distribution of land resources and so forth. Utilization of remote sensing methods for the landslide research it self can be more than one, related to the expected goal, they are visual and digital imagery interpretation methods (Heng, 2013). Method of visual interpretation used to determine the location of landslide and build key interpretation because with this method, the interpreter may take into account the 
Puturuhu, F., Danoedoro, P., Sartohadi, J. and Srihadmoko, D. (2017). The Development of Interpretataion Method For Remote Sensing Imagery In Determining The Candidate of Landslide In Leitimur Paninsula, Ambon Island. Jurnal IImu Lingkungan, 15(1), 20-34, doi:10.14710/jil.15.1.20-34

context of the spatial region with the involvement of more than one element of interpretation, suitable for the equatorial region that a lot of cloud cover as the research sites and excels in analyzing satellite imagery with such high spatial resolution QuickBird. NDVI is used because it can distinguish dense vegetation and not a meeting, as an approach to determine candidate areas of landslide (Liu et al., 2002; Cheng et al., 2004). OBIA an analysis method to implement advanced digital image with an object classification and segmentation method in image interpretation combines spectral and spatial information. OBIA has the advantage on the separation between objects very accurately, perform the classification based object segmentation (Park and Chi, 2008; Moine et al., 2009; Martha et al., 2010; Stumpf and Kerle, 2011), not based on pixels, and the efficiency of processing time. Its ability to classify information does not depend only on one aspect at each pixel alone but this classification into account several aspects such as texture, scale and color. Interpretation methods of Landslide are still new and can be used also to build key Toposhape interpretation is a model built from SRTM DEM (Yang et al, 2019).

Viewed from a potential disaster there, Indonesia is a country with hazard potential is very high. Geographically, Indonesia is an archipelagic country located at the confluence of three tectonic plates, the Australian Plate, the Eurasian and Pacific plates. Indonesia strongly influenced by the form tektonisme endogenous activity and volcanism. The potential for natural disasters include earthquakes, tsunamis, floods, landslide, hurricanes, forest fires and land, as well as volcanic eruptions. Landslide is one of the many natural disasters that occur in the world and ranks third after the earthquakes, and volcanoes, even in Indonesia since the 2002-2006 landslide events including second place after the recent floods (BAKORNAS PB, 2007), and since 18152012 including third place after the recent floods and tornados (BNPB, 2012) .

Ambon Island is one of the islands in Maluku province that belongs to the category of small island with an area of $377 \mathrm{~km} 2$. The population based on the results of the 2010 census as many as 331254 people, with an average density of 2006-2010 which is about 912.07 inhabitants per $\mathrm{km} 2$, is still relatively low density, diverse landscape of the hill, old volcanoes, mountains denudasional, and there are many alluvium plains but not too extensive territory than other landscape (Monk, 1997). This physical condition indicates that the island is prone to natural disasters, and recorded the largest natural disaster in the island of Ambon is landslide, after which followed the flood event.

Leitimur Jaizirah which is one of the Jaizirahs in the South Island with an area of $152.8 \mathrm{~km} 2$ or $41 \%$ of the overall area of Ambon island, includes four subdistricts Nusanive, Sirimau, Ambon Baguala Lake and South Leitimur. Whilst, the central city of Ambon, including the region, Letimur Jaizirah has physiographic conditions which are varied from the plains, hills and mountains. The hills and mountains is a vast territory and occupied by residents with medium density is 1315.3 inhabitants $/ \mathrm{km} 2$, mainly in Sub Nusanive and Sirimau. The region recorded almost every year has been experienced the landslide event.

Given the impact caused by disasters landslide, then the identification of areas of occurrence landslide was felt important to do in order to know the main causes and characteristics of each of landslide event in the research location on Leitimur Jaizirah, Ambon Island, as a first step of prevention and an effort to minimize losses due to landslide disaster, The purpose of this study was to compare the accuracy of the method of interpretation and determine the location of the landslide event.

\section{Methodology}

The chosen area as the research location to assess the event of Landslide Disaster is in Leitimur Paninsula, Ambon Island (Figure 1).

Secondary data that collected to support the implementation of research in Leitimur Paninsula was remote sensing imagery, and map secondary. The imagery used was low and high resolution imagery, and that available for use in this study was Landsat 8, and a Quickbird imagery and SRTM imagery in Ambon Island, the resolution of $30 \times 30 \mathrm{~m}$. Landsat 8 Leitimur Paninsula was fully used for supervised the classification. The Map that collected for the needs of this research was geological maps, soil maps in Leitimur Paninsula, the Topography map was derived from Geospatial Information Agency (BIG).

The initial imagery interpretation was done by carrying out a visual imagery interpretation with imagery interpretation of layered approach to determine the candidate of landslide, once that was done the elements of interpretation. The layerInterpretation that used was a layer of a first-class slope, a second layer of soil, the third layer settlement, the reeds, shrubs, and the last elements of interpretation. A Layered of imagery interpretation was performed using the Quickbird imagery. Each of the overlay on imagery and restricted areas that were known as the landslide candidates interpreted visually by using the elements of interpretation using remote sensing imagery.

The digital/automatic interpretation was undertaken to determine the location of the research location of Landslide Event, was also done through two methods: spectral transformation, combined with multispectral classification and OBIA. Interpretation locations digitally of the Landslide with spectral transformation method was performed on a composite of Landsat 8 with 653 for the training area. Furthermore, the index vegetation NDVI was processed by using a calculator on a raster map, algebra tools in ArcGIS 10 with the input of NDVI's formula:

$\mathrm{NDVI}=((\mathrm{B} 5-\mathrm{B} 4)) /(\mathrm{B} 5+\mathrm{B} 4))$ 


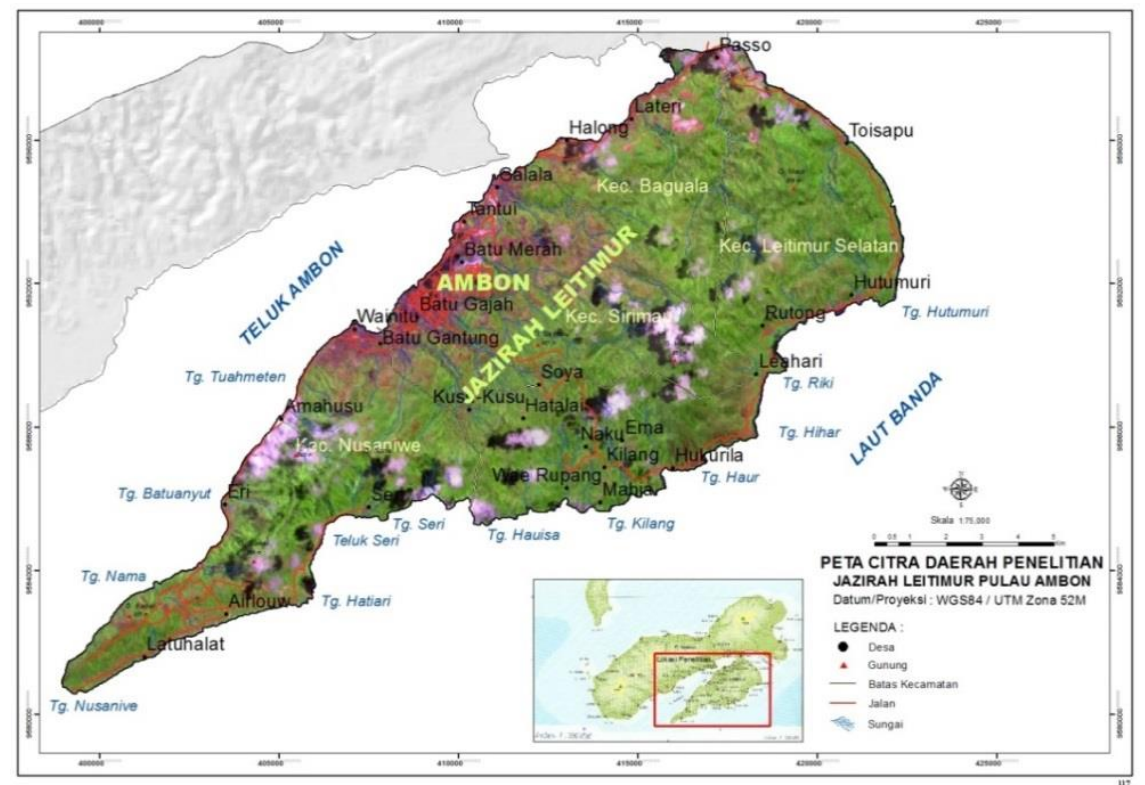

Figure 1. Research Location Map in Leitimur Paninsula, Ambon Island

B5 = Band 5 (Infrared Channel nearby Landsat 7 ETM+) On Landsat 8 is similar to Band 6.

B4 = Band 4 (Infrard Channel nearby Landsat 7 ETM+) On Landsat 8 is similar to Band 5.

Once generated imagery of NDVI with the range of values -1 and +1 , the imagery was then reclassified into three classes, namely rare, medium and meetings. The class vegetation density and the lowest were assumed as the open area (Lin et al., 2002):. To obtain or interpret the scene of landslide was therefore a bit difficult, because the landslide was not appeared on the Landsat 8. Therefore, the overlay of slope class was derived from DEM, with the requirements of the slopes $>15 \%$ acquired acreage that may occur landslide or in this case location including landslides' candidate.

The OBIA method which was a method of digital imagery interpretation advanced as proposed by Martha et al (2010); Danoedoro (2012)., processed by software Idrisi Selva to the stages of segmentation and classification. In the segmentation process there are several stages: a) segmentation to determine how large a vector segmentation is used, b) training segmentaation to make traning area for the land cover, c) carried out the classification with maximum likelihood algorithm, and d) is performed segmentation for the land cover classification (Laliberte et al. 2004). This segmentation resulting from the classification of land cover classification, with the open land as a candidate of landslide.

Toposhape is a specific form of land, which is made in automation in the software Idrisi Selva. Site-specific shape/form that resulting topography consists of 12 feature topography (Eastman, 2012). The first step in making Toposhape is that creating the SRTM DEM Imagery, and then converted it to a format geotif. Once it was subsequently made the Toposhape on Idrisi
Selva, the final result of a spatial form of toposhape and legend clases was used for spatial analysis of landslide scene. To generate candidate of landslide then the reclassification of the results of the classification toposhape above, was using two methods, namely Maximum Likelihood classification using the training area, and classification with Conversion from raster tools in ArcGIS.

The fieldwork of the research study includes determining the spread of the scene of landslide, based on the interpretation or forum tentative sceneof landslide, and make observations and measurements from one location to another include: observation of land cover, type identification of landslide, measuring the slope (percentage of slope, forms a slope (curvature)) and several other parameters are related to landslide. The result of landslide interpretation's scene of both visual and digital methods further were overlaid with the point of the actual scene of landslide found in the reserch location. The actual number of landslide was found in the area of landslide; candidate of landslide and non-candidate landslide included in the table of accuracy test on each method of interpretation to determine how the result percentage of test is. Either singly or with a combination of methods.

\section{Result and Discussion Visual interpretation}

In order to analyze the remote sensing imagery, known as interpretation of remote sensing imagery a ssupposed by Estes et al (1983) in Sutanto (1994), has provided a conceptual framework imagery analysis which is divided into two major parts of the imagery analysis manually (visually) and imagery analysis digitally,

Analysis of visual imagery for the determination of candidate of landslide in this study 
did not directly use the elements of interpretation as usual, but use the construction of LayeredInterpretation, where interpretation of landslide was done through some secondary data map, overlaaid with Quickbird imagery to produce a candidate area of landslide, Layered-Interpretation was carried out in two stages, the first interpretation related to biophysical parameters of landslide, and the second, the interpretations was done by using elements of interpretation as shown in Figure 2.

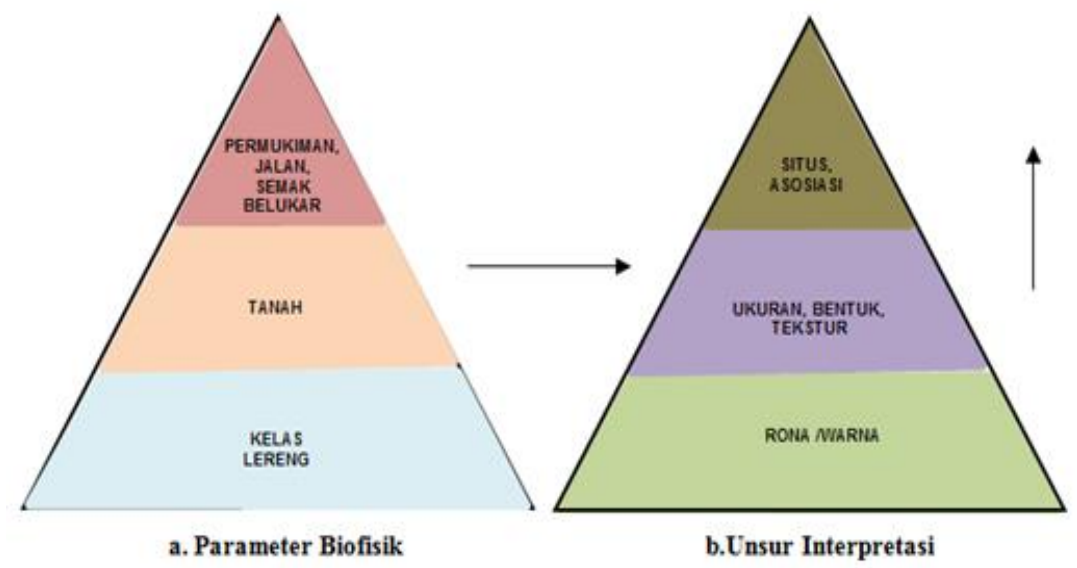

Figure 2. The Pyramid of Layered-Interpretation Approach for Landslide

A layered-Interpretation was done to generate the candidate of landslide on Quickbird imagery, starting with a overlay data of slope class map. Slopes is the approach used in the first layer to do interpretation of the candidate of landslide. The slope on the landslide event is a dynamic triggering factor that is also very influential. So although lithology, soil, and landcover that included in the candidate of landslide, but because of the slope was great and the effect on landslide event, it will be eliminated (Martha et al.,2010). From various studies that have been conducted by several researchers, the slope of $>15 \%$ is a slope that had many events of landslide, and below of the percentage is rare even though if there is landslide event caused by erosion of the river banks. Therefore, an area that was eliminated at this layer is the area with the slope grade below $15 \%$ or L2, so the cotton area is 7982.88 landslide' canddidates (88.25\%), and the area is eliminated increasingly becoming $1063.01 \mathrm{ha}$. Land used as a second layer in a layered-interpretation, since land is the result of weathering lithology and included more than its effect on the landslide event on lithology. Therefore, not all of the lands that were produced or which were at lithology counts as a candidate on the first layer in or become a candidate at this layer. Particularly those in the region of plains and depression. Interpretation of results obtained comprehensive approach to the candidate of landslide is 7921.21 ha $(87.57 \%)$, which was known as an eliminated area of 1124.68 ha. The land that is entered as a candidate of landslide is Podsolic, Kambisol, Brunizem, Rendsina.

For Alluvial, Regosol and Litosol will enter a candidate of landslide if it is on a slope of $>15 \%$. Otherwise not so for Gleisol where the soil is eliminated at various grade slopes and considered no effect on the landslide event because they are in depressed areas or basin.

Settlements and roads as well as reeds and shrubs, both land cover is important as an approach for determining candidate of landslide, because landslide event was occurred at the area with a slope grade is > $15 \%$. Thus the extent of the landslide area is an eligible candidate for visually interpretable remaining of 1821.38 ha $(20.14 \%)$, and the area is eliminated and does not need to interpret the greater one is 7224.51 ha. Whilst, construction of multi-layered approach to determine the candidate of landslide and in conjunction with Visual Imagery Interpretation with elements of interpretation and interpretation of several locations of landslide are presented in Figure 3.

The elements of interpretation used for interpretation of landslide in the research location using Quickbird imagery is a color /tone, shape, size and texture. While, in the research location was used the association with the help of local knowledge (Speight, 1977; Rib and Liang, 1978; van Zuidam, 1985; Antonini et al., 2002a, 2002b). The introduction of a single landslide opens without land cover, yellow or brown with light tones such as Wawekang Amahusus and Hatalae 1. Menawhile, to soil creep color is varied and its tone is dark to light, due to the influence of settlements and garden plants. The shape of landslide appears irregularly or no length wise with a large circle on top and vice versa. The size varies, but for the type of soil creep on average large in size and is located in all residential areas with steep to a very steep slopes, rough texture, the location is located generally in the hilly and mountainous areas and association on the slopes on to the slopes. 


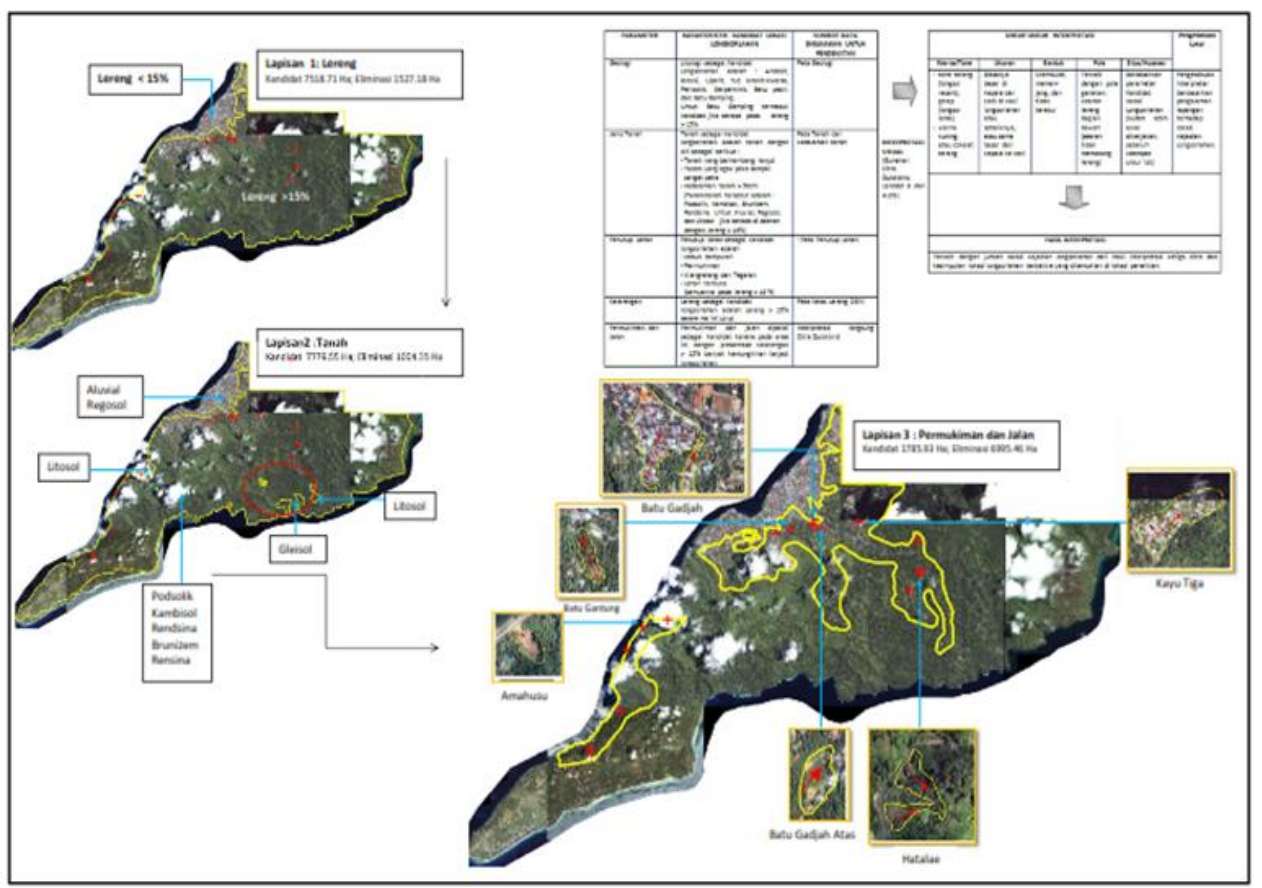

Figure 3. The Construction of a Layered Approach for the Visual Interpretation of Landslide

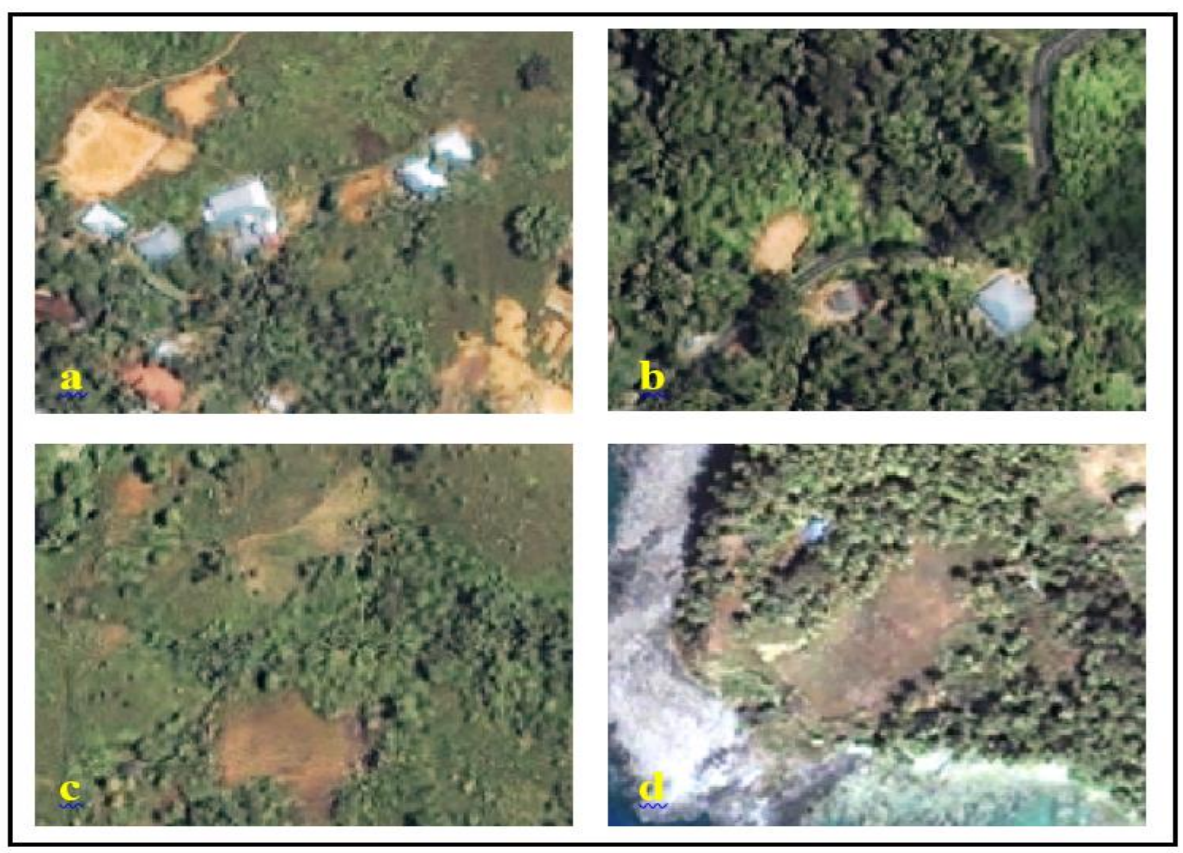

Figure 4. The Quickbird Imagery Appearance Model, from the Location which is similar The Landslide Area, Scale 1:1500. a).Settlement, b) Cutting of the Road, c,d) Open land/Field/Moor

On Quickbird imagery with a resolution of $2.4 \mathrm{~m}$, it is still difficult to define or distinguish the typeof landslide. The size of the total of landslide is 17,400 m2 represented by 7,250 pixels, and smallest landslide with an area of $1,500 \mathrm{~m} 2$ is represented by 625 pixels.
To answer the above conditions in determining the location of landslide in the imagery or map Leitimur Paninsula Ambon Island, which mostly occurs in a residential area that slopes in the physiographic hilly and mountainous, having a data point of field observations and local knowledge about the scene of landslide and the surrounding area, Local knowledge 
is important because in Ambon there are many locations when it is viewed from the high-resolution imagery yet of aerial photographs is the same of landslide location, for example: the location of the real estate / housing built by developers in the slope or hilltop area (local Lateri, Garden Clove) , the location of excavation $\mathrm{C}$ which is better known as the sand/rock mountains (Regional Wayori-Passo), and the location of the slope was cut to the road line, although this also has an impact on the landslide event (eg, in the District of South Leitimur and Nusanive), open land ( yard, field prepared for replanting, beraa land, and so on). Some examples of the appearance of the imagery of a location is similar to landslide, is presented in Figure 4.

On previous study was using aerial photography, as practiced by Soejitno (1995) which generates a common trait landslide scene; Zamba and Mene (1969) in Joyosuharto (1980) characterized the landslide using aerial photographs for the type of slump; and Joyosuharto (1980) which produces the characteristic of landslide type of slide, slump, flow and creep from aerial photographs. This shows that the large-scale of aerial photography can provide a detailed of landslide characteristics to determine the typ of landslide. Remote Sensing Imagery Satellite with a high resolution such as QuickBird, IKONOS, can give the same result if the climatic conditions of the landslide event area is a dried area so no effect of vegetation cover, landslide size is large, and to the extent possible its own imagery shows a threedimensional appearance/streoskopis.

\section{Digital-Automatic Interpretation}

Image classification digitally perform automatic categorization of all image pixels into classes of land cover or a specific theme, thus digitalautomatic interpretation is still required as a way to quantify the characteristics of the object.

\section{Spectral transformation}

The result of spectral transformation, NDVI for the first landslide event has produced two classes whichare not meeting and the meeting is worth -1 (non vegetation) and +1 (vegetation). Then, there are reclassified into three classes, namely low density with a value of $-0.14-0.23$, while the value of 0.23 to 0.39 and a high value of 0.39 to 0.63 . The purpose of reclassification is so far that the area is not considered a meeting and synonymous with the open land as a candidate of landslide. Because the density was still considered to be the area that is not too tight closure of vegetation, as well as mixed garden, some of slightly open, so as a candidate of landslide was combined into NDVI classes; low and medium density. From the result of the merger of the two levels of this density, which is not included in the candidate landslide is a sloped area below 15\%. With NDVI determining the location of a single landslide event, it was a bit difficult because the imagery resolution and the measurement of landslide is not too wide, where the maximum measurement of landslide is $17,400 \mathrm{~m} 2$ encountered or 19 pixel imagery on Landat 8, including the type of soil creep is still covered with settlements and vegetation.

In contrast to this, the research that was conducted by Barlow et al (2003) in the drainage basin Chilliwack, Vancouver U.S.-Canada, with different climatic conditions are humid alpine basin., large size of landslide, and the presence of rock out crop, talus and snow.

\section{Object Based Image Analysis (OBIA)}

Object based classification is able to define the object classes based on aspects of spectral and spatial aspects as well, as proposed by Hurd et al (2006) in Wibowo (2012). The object is formed through a process of segmentation which is the process of grouping the adjacent pixels with the same quality (spectral similarity).

In general the classification process was done by the method OBIA through two main stages, namely imagery segmentation and classification of each segmentation (Xiaoxia et al, 2004). Classification method, Idrisi Selva OBIA, the software is very simple compared to other software such as classification eCognition, and Spring. In Idrisi ahas only four steps that developed from two main stages, namely: segment training, maximum likelihood and segmentation classification. At the stage of segmentation included three bands or raster group, the band composite on Landsat 8 is 6 bands, band 5 and band 3 with a window with 3 , similarity tolerance or segmentation vector 20,30 and 50 , weight mean and variance of weight vector is the same, namely 0.5 . The accuracy is best to do calcification using a tolerance similarity of 50 with percentage of its accuracy of $38.9 \%$. with this tolerance similarity cause the presence of landslide in the research and the candidate of landslide is greater than the classification by using the similarity tolerance 20 and 30 , as shown in Figure 5.

Similar to the result of spectral transformation, OBIA method was used to digitally do interpretation of landslide in the research locations in the Leitimur Paninsula, also it produces the candidate of landslide in the research locations based on the spread of open land and settlements with the provisions that is in slopes of $>15 \%$. It is not producing a single of landslide as did Barlow et al (2003), and other researchers are using segmentation method to study the landslide. The difference with the research was conducted that the influence of vegetation cover is very large, low imagery resolution and the size of smalll landslide. However, the segmentation of land cover for acquisition the candidate of landslide method OBIA is the process of more systematic, easy and the result is quite good. 


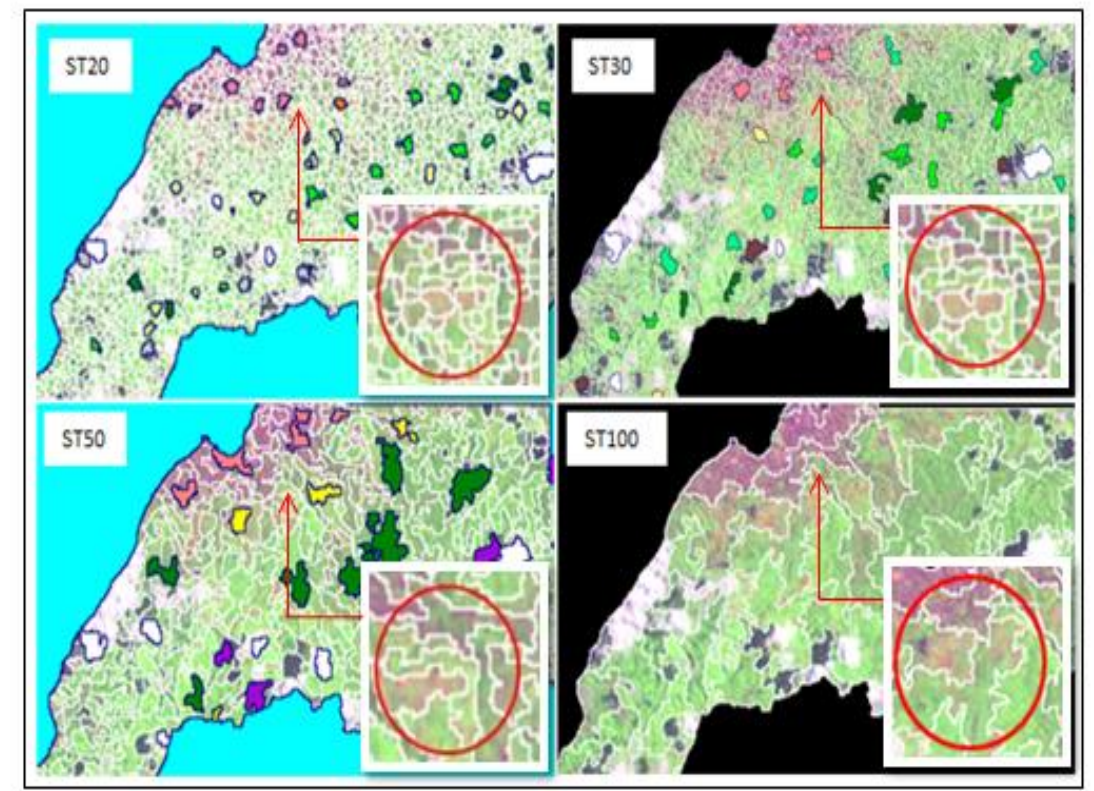

Figure 5. Comparison of the Similarity Tolerance on Landsat Imagery 8 That used in the segmentation of Landcover

\section{Toposhape Model of Landslide}

The genesis of landslide besides has influenced by various factors mentioned in the previous section, the differentiation of these factors are expressed through topography also very influential. Many studies using toposhape especially as one of the factors or parameters in determining the vulnerability landslide, for example by Ercanoglu (2005), where he uses the toposhape to evaluate the relationship between topography and landslide.

Toposhape is classified topography into 12 classes consisting of: peak (peak), ridge (back / peak-shaped long and narrow), saddle (the ridge between two mountain peaks), flat (flat), ravine (ravine / valley ), pit (hole), convex hillside (slope convex), saddle hillside (ridge), slope hillside (hillside), concave hillside (slope concave), inflection hillside (form slopes that are changing), and unknown hillside (slope unknown) (Eastman, 2012). Toposhape built or created from SRTM DEM imagery with a resolution of $30 \times 30 \mathrm{~m}$, Toposhape found at the study area that there are 11 classes. Classes that there is a peak (peak), this is possible because the area of Leitimur Paninsula was used to create toposhape of landslide event yet to be at the highest peak, and most of the event of landslide is located in the hilly region.

From the results that obtained that the grade of automation of toposhape was spacious and has large pixel and more on the overall study area is saddle hillside (ridge) with an area of 3,455 ha (12\%) and the number of pixels $55445(12 \%)$. It is strongly supported by the condition of Leitimur Paninsula area which is largely dominated by local undulating, hilly and mountainous. In addition to the flat, then the class which has the smallest pixel area and hillside slope (hillside) which is 4 ha $(0.01 \%)$ and the number of pixels $67(0.02 \%)$.

To produce the candidate area of landslide then the results should be reclassified on to toposhape automation using Maximum Likelihood classification and Conversion tools from raster into two classes, namely the candidate area of landslide and non candidate area of landslide. The topography was used as candidate landslide is hollow and ridge, Based on the results obtained that the reclassification of the candidate area of landslide on Maximum Likelihood classification does not vary much with candidate area of landslide with classification Conversion from raster tools are 2510.36 and $2521.28 \mathrm{Ha} \mathrm{Ha}$, the difference of 10.92 hectares, as the position of the area too.

The type of landslide was found at the research location where there are 5 soil rotational slide, soil creep, the flow of material destruction (debris flow), landslides translation with soil materials (earths Slide), multiple rotational slide. Surely this type has associated within and conditions around the scene of landslide is more to do with landforms and topography.

Several previous studies that conducted by Canianiet (2008) in Feryandi (2011), topography influencing onlandslide event, which according to research results almost all of landslide events were found to occur in the form of topographic hillside (slope Hillshade), and rarely occurs in the form of topography peak, flat and pit (hole). As supported by Ercanoglu (2005), carrying out a study to look at the relationship between topography (toposhape) andlandslide, where he concluded that landslide occurs in areas with the low topographic elevation and covered by soils derived 
Puturuhu, F., Danoedoro, P., Sartohadi, J. and Srihadmoko, D. (2017). The Development of Interpretataion Method For Remote Sensing Imagery In Determining The Candidate of Landslide In Leitimur Paninsula, Ambon Island. Jurnal Ilmu Lingkungan, 15(1), 20-34, doi:10.14710/jil.15.1.20-34

from Ulus formation. Related to topography was found that the convex and concave hillsides are particularly vulnerable to event of landslide.

Previous studies did not vary much with the results of the analysis of automation with Idrisi in the research location of Leitimur Paninsula. As presented in Table
1 which is extracted toposhape for each scene of landslide of the research location, can be explained as follows.

Table 1. The Type of Landslide and Toposhape

\begin{tabular}{|c|c|c|c|c|c|}
\hline Landslide Location & $\begin{array}{l}\text { The Type of } \\
\text { Landslide }\end{array}$ & Toposhape & $\begin{array}{c}\text { Feature of } \\
\text { Topography }\end{array}$ & $\begin{array}{l}\text { The Actual } \\
\text { Condition of } \\
\text { Lanslide }\end{array}$ & $\begin{array}{r}\text { Width } \\
\left(\mathrm{m}^{2}\right)\end{array}$ \\
\hline Waemekang & Rotational slide & & ravine, ridge & & 2.500 \\
\hline $\begin{array}{l}\text { Batu Gadjah } \\
\text { Atas }\end{array}$ & Rotational slide & & $\begin{array}{l}\text { saddle hillshade, } \\
\text { concave hillshade }\end{array}$ & & 7.200 \\
\hline Naropang & $\begin{array}{l}\text { Multiple rotational } \\
\text { slide }\end{array}$ & & $\begin{array}{l}\text { saddle hillshade, } \\
\text { concave hillshade }\end{array}$ & & 1.700 \\
\hline Hatuwaeng Eri & $\begin{array}{l}\text { Multiple rotational } \\
\text { slide }\end{array}$ & & $\begin{array}{l}\text { saddle hilshade, } \\
\text { ravine }\end{array}$ & & 5.175 \\
\hline Manggadua & Earth slide & & $\begin{array}{l}\text { saddle hillshade, } \\
\text { ridge }\end{array}$ & & 2.200 \\
\hline $\begin{array}{l}\text { Batu Gadjah } \\
\text { Bawah2 }\end{array}$ & Debris flow & & saddle hiilshade & & 3.500 \\
\hline Bubawang & Debris flow & & $\begin{array}{l}\text { saddle hillshade, } \\
\text { concave hillshade, } \\
\text { convex hillshade }\end{array}$ & & 7.000 \\
\hline Kayu Tiga & Soil creep & & $\begin{array}{l}\text { saddle hilshade, } \\
\text { concave hillshade, } \\
\text { ravine }\end{array}$ & & 7.200 \\
\hline $\begin{array}{l}\text { Batu Gadjah } \\
\text { Bawah1 }\end{array}$ & Soil creep & & $\begin{array}{l}\text { saddle hillshade, } \\
\text { concave hillshade }\end{array}$ & & 2.400 \\
\hline Silale & Soil creep & & $\begin{array}{l}\text { convex } \\
\text { hillshade, ridge }\end{array}$ & & 17.400 \\
\hline
\end{tabular}




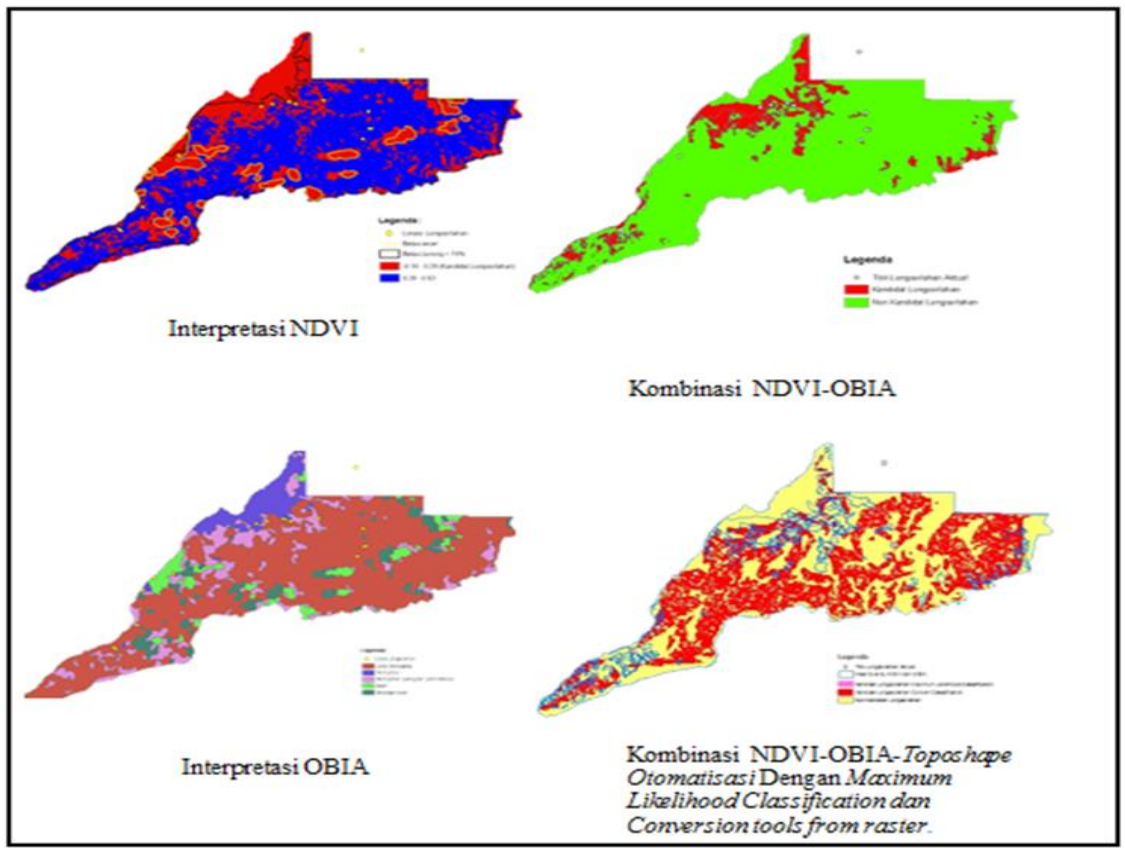

Figure 6. The Comparison of Intrepretation for the Landslide Candidate Using Remote Sensing and Its Combination

Overall the scene landslide toposhape classes that are found and are very vulnerable to events affecting or landslide based on Table 1 above is a ridge (saddle hillside / ridge) and concave slope (concave hillside). According Metrics Smorph, concave slope with a slope angle of $15-25 \%$ excluding alert (vulnerability landslide medium), concave slope with a slope angle of 25 -> 65\%, including unstable (high landslide vulnerability. So logically if concave slope much going landslide. The ridge itself a byproduct of the concave slope. Many landslide happened on concave slope that is part of the ridge (movement cut backs is not unidirectional).

The influence of toposhape in the slope on the type landslide was happened relatively in other regions too where it was not all exactly the same as generated in this study, since the landslide event was not merely from the slope as a major factor, there are other factors that influence both static and dynamic.
Comparison of Methods on Interpretation of Genesis in the Landslide Location

Besides the interpretation of a single landslide by using the three methods of remote sensing above (NDVI, OBIA, and Toposhape), then to get the better accuracy interpretation, has been made a combination of interpretation that NDVI-OBIA, and NDVI-OBIA-Toposhape as shown in (Figure 6)

From the result of overlay-OBIA NDVI and NDVI-OBIA-Toposhape, spacious has obtained a candidate location of landslide was increased, but the number of actual of landslide included in the candidate of landslide which it was not increased. This is because the addition was took place outside of the actual landslide scene. There are many candidates of landslide were unrecorded due to the closure of clouds and shadows. See matrix combination relationship in Table 2-7.

Table 2. The Accuracy Test for the Result of the Visual Interpretation

\begin{tabular}{|c|c|c|c|c|}
\hline \multirow{2}{*}{} & \multicolumn{2}{|c|}{ Visual Interpretation } & Total \\
\cline { 3 - 5 } \multicolumn{2}{|c|}{ Field } & $\begin{array}{c}\text { Landslide's } \\
\text { Candidate }\end{array}$ & $\begin{array}{c}\text { Non-Landslide's } \\
\text { Candidate }\end{array}$ & \\
\hline \multirow{3}{*}{} & $\begin{array}{c}\text { Landslide's } \\
\text { Candidate }\end{array}$ & $\mathbf{1 7}$ & 1 & 18 \\
\cline { 2 - 5 } & $\begin{array}{c}\text { Non-Landslide's } \\
\text { Candidate }\end{array}$ & 1 & $\mathbf{1}$ & 2 \\
\hline & & 18 & 2 & $\mathbf{2 0}$ \\
\hline
\end{tabular}

The Accuracy Result of the total Interpretation: $18 / 20=90 \%$ 
Puturuhu, F., Danoedoro, P., Sartohadi, J. and Srihadmoko, D. (2017). The Development of Interpretataion Method For Remote Sensing Imagery In Determining The Candidate of Landslide In Leitimur Paninsula, Ambon Island. Jurnal Ilmu Lingkungan, 15(1), 20-34, doi:10.14710/jil.15.1.20-34

\begin{tabular}{|c|c|c|c|c|}
\hline \multicolumn{2}{|c|}{} & \multicolumn{2}{|c|}{ NDVI } & Total \\
\cline { 3 - 5 } & $\begin{array}{c}\text { Landslide's } \\
\text { Candidate }\end{array}$ & $\begin{array}{c}\text { Non- Landslide's } \\
\text { Candidate }\end{array}$ & 18 \\
\hline \multirow{3}{*}{ Field } & $\begin{array}{c}\text { Landslide's } \\
\text { Candidate }\end{array}$ & $\mathbf{8}$ & 10 & 20 \\
\cline { 2 - 5 } & $\begin{array}{c}\text { Non- } \\
\text { Landslide's } \\
\text { Candidate }\end{array}$ & 10 & $\mathbf{1 0}$ & $\mathbf{3 8}$ \\
\hline & & 18 & 20 & 20 \\
\hline
\end{tabular}

The Accuracy Result of the total Interpretation: $18 / 38=47 \%$

Table 4. The Accuracy Test for the Result of the Visual Interpretation of OBIA

\begin{tabular}{|c|c|c|c|c|}
\hline \multirow{2}{*}{} & \multicolumn{2}{|c|}{ OBIA } & Total \\
\cline { 3 - 5 } & $\begin{array}{c}\text { Landslide's } \\
\text { Candidate }\end{array}$ & $\begin{array}{c}\text { Non - Landslide's } \\
\text { Candidate }\end{array}$ & 18 \\
\hline \multirow{3}{*}{ Field } & $\begin{array}{c}\text { Landslide's } \\
\text { Candidate }\end{array}$ & $\mathbf{7}$ & 11 & 22 \\
\cline { 2 - 5 } & $\begin{array}{c}\text { Non- } \\
\text { Landslide's } \\
\text { Candidate }\end{array}$ & 11 & $\mathbf{1 1}$ & $\mathbf{4 0}$ \\
\hline
\end{tabular}

The Accuracy Result of the total Interpretation: $18 / 40=45 \%$

Tabel 5. The Accuracy Test for the Result of the Visual Interpretation of Toposhape

\begin{tabular}{|c|c|c|c|c|}
\hline \multicolumn{2}{|c|}{} & \multicolumn{2}{|c|}{ Toposhape } & Total \\
\cline { 3 - 5 } & $\begin{array}{c}\text { Landslide's } \\
\text { Candidate }\end{array}$ & $\begin{array}{c}\text { Non - Landslide's } \\
\text { Candidate }\end{array}$ & 18 \\
\hline \multirow{3}{*}{ Field } & $\begin{array}{c}\text { Landslide's } \\
\text { Candidate }\end{array}$ & $\mathbf{8}$ & 10 & 20 \\
\cline { 2 - 5 } & $\begin{array}{c}\text { Non- } \\
\text { Landslide's } \\
\text { Candidate }\end{array}$ & 10 & $\mathbf{1 0}$ & $\mathbf{3 8}$ \\
\hline
\end{tabular}

The Accuracy Result of the total Interpretation: $18 / 38=47 \%$

Tabel 6. The Accuracy Test for the Result of the Visual Interpretation of the CombinationNDVI-OBIA

\begin{tabular}{|c|c|c|c|c|}
\hline \multicolumn{2}{|c|}{} & \multicolumn{2}{|c|}{ NDVI-OBIA } & Total \\
\cline { 3 - 5 } \multicolumn{2}{|c|}{} & $\begin{array}{c}\text { Landslide's } \\
\text { Candidate }\end{array}$ & $\begin{array}{c}\text { Landslide's } \\
\text { Candidate }\end{array}$ & 18 \\
\hline \multirow{3}{*}{ Field } & $\begin{array}{c}\text { Landslide's } \\
\text { Candidate }\end{array}$ & $\mathbf{8}$ & 10 & 20 \\
\cline { 2 - 5 } & $\begin{array}{c}\text { Non- } \\
\text { Landslide's } \\
\text { Candidate }\end{array}$ & 10 & $\mathbf{1 0}$ & $\mathbf{3 8}$ \\
\hline
\end{tabular}

The Accuracy Result of the total Interpretation: $18 / 38=47 \%$

Table 7. The Accuracy Test for the Result of the Visual Interpretation of the Combination NDVI-OBIA-Toposhape

\begin{tabular}{|c|c|c|c|c|}
\hline \multirow{2}{*}{} & \multicolumn{2}{|c|}{ NDVI-0BIA-Toposhape } & Total \\
\cline { 3 - 5 } & $\begin{array}{c}\text { Landslide's } \\
\text { Candidate }\end{array}$ & $\begin{array}{c}\text { Non- Landslide's } \\
\text { Candidate }\end{array}$ & 18 \\
\hline \multirow{3}{*}{ Field } & $\begin{array}{c}\text { Landslide's } \\
\text { Candidate }\end{array}$ & $\mathbf{1 0}$ & 8 & 16 \\
\cline { 2 - 5 } & $\begin{array}{c}\text { Non- } \\
\text { Landslide's } \\
\text { Candidate }\end{array}$ & 8 & $\mathbf{8}$ & $\mathbf{3 4}$ \\
\hline
\end{tabular}

The Accuracy Result of the total Interpretation: $18 / 34=53 \%$ 
Thus the comparison of the accuracy of results for the landslide interpretation are summarized in Table 8 below.

Table 8. The Comparison of Intrepretation Result in the Research Location of Landslide Event From the 4 Methods and their Combination

\begin{tabular}{|c|c|c|}
\hline Interpertation Method & $\begin{array}{c}\text { The Satelite Imagery was } \\
\text { used }\end{array}$ & Accuracy \\
\hline Visual Interpretation & Quickbird & $90 \%$ \\
\hline NDVI & Landsat 8 $\%$ \\
\hline OBIA & Landsat 8 & $45 \%$ \\
\hline Toposhape & SRTM & $47 \%$ \\
\hline NDVI-OBIA & Landsat 8 & $47 \%$ \\
\hline NDVI-OBIA-Toposhape & Landsat 8, SRTM & $53 \%$ \\
\hline
\end{tabular}

From the results of this comparison, the best method is used for the interpretation of the scene is a visual interpretation layered of landslide is with 90\% accuracy. It is a high accuracy of visual interpretation because all of landslides were occured within the limits of candidate of landslide in the research location, although ssome were found on the outside. For digital interpretation, the actual number of NDVI of the landslide was equal to Toposhape and also the same as the NDVI-OBIA. The comparison of five digital interpretations to determine a candidate of landslide (other than visual interpretation), the result overlay NDVI-OBIA-Toposhape having a percentage accuracy is better at $53 \%$. The high percentage of digital interpretation occurs in many combinations using the method, so that the scene single interpretation method of landslide was not included in the candidate of landslide, in various combinations be included in the candidate of landslide.

The low percentage of accuracy of the method NDVI, and OBIA, in addition to not be able to display the scene landslide, then the spread of landslides too proportional candidates as influenced by land cover another color is almost the same as the open land is indicated as the location landslide land cover settlements. Will produce good interpretation if using a high-resolution image, with a plot that is not too large on its widthsampling, and software that supports these characteristics is the weakness of interpretation by using segmentation or OBIA. If the locations studied had the landslide in large size and limits expressly to cover other land in the vicinity, then of course the result of precision is to be high, it may be the same as the visual interpretation. One important thing that the landslide is the domain of "terrain", therefore if using digital imagery interpretation that relies on the reflection spectral then the more dominant resulting in the classification is biotic elements or vegetation, especially in the area of sub-tropical climate that land cover by vegetation meetings. Thus causing the value percentage of accuracy on NDVI and OBIA, or combinations thereof. The low value of the percentage of accuracy Toposhape because it is determined from the position of topographic features that influence the event of landslide like the ridge and concave slope.

\section{The Distribution and Typology of Landslide}

Based on the interpretation of visual, digital and field studies, as well as secondary data, was obtained tentatively the landlislide taht happened in Leitimur Paninsula, Ambon Island from the year 2008-2013, with various sizes and effects which there are about 43 locations of landslide, but not all examined in this study.

Table 9. Landslide Distribution in Eevry Subdistrict-Village based on Year Event and Width

\begin{tabular}{|l|l|l|c|r|}
\hline \multicolumn{1}{|c|}{ Subditrict } & \multicolumn{1}{|c|}{ Village } & \multicolumn{1}{|c|}{ Year Event } & $\begin{array}{c}\text { The total } \\
\text { Event of } \\
\text { Landslide }\end{array}$ & Width (m ${ }^{2}$ ) \\
\hline Baguala & Passo & 2012 & 1 & 1.600 \\
\hline Sirimau & & 2013 & 2 & 14.000 \\
\hline & Batumerah & $2012-2013$ & 2 & 8.700 \\
\hline & Soya & $2008,2011-2013$ & 3 & 13.100 \\
\hline & Batu Gadjah & 2012 & 1 & 2.200 \\
\hline & Mangga Dua & & 3 & 4.575 \\
\hline South Leitimur & Hatalae & 2008,2013 & 1 & 12.500 \\
\hline & Hukurila & 2012 & 3 & 11.200 \\
\hline Nusanive & & $1982,1987,2008$, & 1 & 17.400 \\
\hline & Amahusu & 2013 & 1 & 5.175 \\
\hline
\end{tabular}


Landslide event was examined in this study and used of modeling was the landslide with a size of more than $1,500 \mathrm{~m} 2$. This is due to landslide size is smaller than this and spread in several locations in Leitimur Paninsula even among landslide study did not adversely affect humans and the existing infrastructure. Table 9 presents the landslide event per sub-district and village.

Based on observations at 18 points of landslide in Leitimur Paninsula found five typologies of soil rotational slide), soil creep, debris flow, earths Slide, multiple rotational slide, more to the deployment location and number of events are presented in Table 10.

Soil Rotational Slide is caused landslide by the collapse via sliding plane with its material composition has not changed much and is generally influenced by rotational motion or the motion curve. Soil Rotational Slide found at the study site there are seven events with area 1500-7200 m2. Located at the unit of land form hills and mountains with slopes ranging between $50-80 \%$ straight to convex shaped. Conditions steep slopes to very steep and cutting slopes for the construction of roads such as on-site controller Wawekang Amahusu into the landslide triggered by the presence of personnel who work in the form of water under the influence of very high rainfall. Besides, it is also the effect of high intensity rainfall in the month of June 2012 is $1,252 \mathrm{~mm} / \mathrm{h}$, which coincides with the earthquake in the time interval that is not much different for the week of June 17,2012 with a magnitude of 3.8 SR depth of $10 \mathrm{~km}$ and the position of the epicenter is $1.5 \mathrm{~km}$ Northeast Ambon and supported by a distribution map of the epicenter of the earthquake is felt in Maluku and the surrounding area in 2012, the trigger events in the Batu Gajah landslide Up. Besides the slope, the soil, geology and land use also functions as a controller in the event of a slump landslide/ nendatan. Land Kambisol which bersolum thick with lithology material off that easily weathered and the mixing of the parent material on it or preconceived very susceptible to the occurrence of ground movement or landslide, as well as land use that have been affected by human activities both in the area around the head landslide like in Batu Gajah Up, Soya and Hatalae result in changes in land use to mixed farms, reeds shrubs and even on the road. The opening of the land due to human activities have caused in case of rain water infiltrated into the soil with ease and as it reaches saturation land masses become heavy and will stir downward by gravity through a sliding plane which is curved upward or rotational. Imposition by road with vehicles that passed also affects the event of landslide in Hatalae.

The type of Multiple Rotational Slide is the same Soil Rotational Slide, the difference in addition to several other characteristics of the study sites are the two areas of sliding rotational landslide formed on one incident. Multiple Rotational Slide found as many as two events, namely in Naropang Amahusu and Hatuwaeng Eri with an area of approximately 1,700 to $5,175 \mathrm{~m} 2$. Landslide is located on hilly land forms a unit with a slope of $75-95 \%$ with varied shapes. Factors controllers and triggers were found together with Soil Rotational Slide. Factors that influence the formation of two sliding plane in the incident landslide is varied slope, lithology and distance from the source to the feet of landslide.

Table 10. The Type of Landslide, Distibution and the Total of Event.

\begin{tabular}{|c|c|c|c|c|}
\hline No. & $\begin{array}{l}\text { The Type of } \\
\text { Landslide }\end{array}$ & The locations were found & $\begin{array}{c}\text { Total of } \\
\text { Event }\end{array}$ & Precentage \\
\hline 1. & Soil rotational slide & $\begin{array}{l}\text { Waiory Passo, Kanawa Kebun } \\
\text { Cengkeh, Batu Gadjah Atas, Soya } \\
\text { dan Wawekang Amahusu }\end{array}$ & 7 & $38,9 \%$ \\
\hline 2. & $\begin{array}{l}\text { Multiple Rotational } \\
\text { Slide }\end{array}$ & $\begin{array}{l}\text { Naropang Amahusus dan } \\
\text { Hatuwaeng Eri }\end{array}$ & 2 & $11,1 \%$ \\
\hline 3. & Earth Slide & $\begin{array}{l}\text { Mangga Dua, Batu Merah Atas, } \\
\text { Hukurila dan Hatalae }\end{array}$ & 4 & $22,2 \%$ \\
\hline 4. & Debris Flow & $\begin{array}{l}\text { Batu Gadjah Bawah, dan Bubawang } \\
\text { Amahusu }\end{array}$ & 2 & $11,1 \%$ \\
\hline 5. & Soil creep & $\begin{array}{l}\text { Batu Gadjah Bawah, Silale, dan } \\
\text { Kayu Tiga Soya }\end{array}$ & 3 & $16,7 \%$ \\
\hline
\end{tabular}

The type of Earth Slide occurs because of the sliding plane is flat or linear. This flat sliding plane which causes the ground material can glide with moderate to fast speeds, causing much changed the composition of the material. But in both these locations produced is land and other rough material. Found in 2 locations in Mangga Dua and Hatalae with area 1500-2200 m2. Both landslide unit is located on land form hills and mountains, with a slope of $50-85 \%$ including steep to very steep with a concave shape and irregular. To the terrain sloping and land cover is dominated settlements, and reeds shrubs and ground Kambisol and Rensina who have solum soil moderate to thick, while the high intensity rainfall water will be infiltrated and menjenuhi ground so that the speed of gravity is moderate to fast will launch a mass of soil 
passing through the glide plane flat material Limestone and Granite stem downward. In addition to high rainfall intensity, then that becomes the trigger events landslide is loading on the head landslide area occupied settlements and drivable. The landslide in Manggadua was moving towards the south, Hatalae move to the West.

Type Debris Flow, is the movement of land affected by the amount of content or soil water content, occurs in unconsolidated material. Landslide field between material moving generally unrecognizable. Found on the study site there are two events landslide debris flow material each with an area of $3,500 \mathrm{~m} 2$ and $7,000 \mathrm{~m} 2$. Both landslide is located on the land form units hills with a slope of about $60-70 \%$. Both events landslide This occurs as a result of the rainfall intensity is very high, so that the controlling factor steep slopes to very steep, solum soil thickness of soil Kambisol and Brunizem, as well as land cover residential and mixed garden causes ground movement that are dispatched material soil mixed with water. Litologinya loose material and serpentinite. The landslide on Batu Gajah Down and Bubawang Amahusu brought the material move to follow the preconceived functioning as a river in the rain. At the scene Batu Gajah Down at the landslide are settlements whose activities affect the flow of events landslide this destruction. Directions landslide both lead toward the North.

Type Soil creep is a movement that can be distinguished in terms of the speed of motion is naturally usually slow (Zaruba and Mencl, 1969; Hansen, 1984). Was found in three locations, namely in Batu Gajah events Down with area of 2,400 m2, Wood Three spacious 7,200 m2 and 17,400 m2 Silale.

Batu Gajah Down, happened in 2012, built from the parent material ingredient or los loose material, soil type Kambisol, has a slope of $70 \%$ and landcover settlements. This characteristics into factors causing Soil Creep. Dynamic trigger factor slope, rainfall and land cover, and triggers static rocks and soil. Soil Creep that occurs in locations Batu Gajah Down takes place gradually in a few days.

Occurrence of Soil Creep in the Batu Gajah Below is influenced by various factors above. The slope location of the study $70 \%$ (very steep) that means very susceptible to landslides or the occurrence of soil creep. Deductions slopes to build a house opportunites entry of water into the soil, especially when the rain with a very high number of $639 \mathrm{~mm}$ as happened in August 2012. Water entering a continuous basis will lead to saturation, and the lands as Kambisol and podsolic containing clay shrinks and expands the potential for very high can easily lead to soil creep, coupled with loading rains in July and August 2013, according to information the locals do not happen again Soil Creep. Another cause as a trigger is based on records of tectonic earthquake centered BMKG Soil Creep location when the incident took place. Soil creep occurs within a few days and ended up with the high speed causing some neighborhoods experiencing landslides.

As a result of this incident approximately \pm 50 homes were destroyed or suffered creep by forming a tilt angle of more than $30 \mathrm{o}$. for handling the rehabilitation of the victims, while the government is providing relocation site in the village of Halong.

Three timber, the incidence has occurred in 2010 , and until recently was at a time when rain and earthquakes still occur even though the movement of soil creep in a little intensity. The location is in the creep soil parent material loose material, soil Kambisol, Slope 35\%, and land cover settlements. Factors that trigger the dynamic soil creep Kayu Tiga is rainfall, slope water reservoir and tectonic earthquake, while the static factor of rock and soil. Soil creep that occurs in the Three Wood is happening slowly in recent years. Compared with the location of Batu Gajah Down, Three Wood has a slope that is not too big of a $30 \%$ (rather steep). However, from the results of field research we discovered some point the spring that came out at the foot of the slopes of the location of soil creep. That means there is a layer of rock padas as launchers for land mass moving over it. Movement will be even greater if tectonic earthquake. Silale-Nusanive, happened on 30 July 2013. The location of this Soil Creep is on the parent material Limestone, Rensina soil, slope 35\% (rather steep), and land cover settlements. Factors that trigger the dynamic Soil Creep is water. Static triggers that influence the limestone lithology.

In this study the location of soil creep is not only happens, but it happens as well as follow-up subsidence of soil sreep events that destroyed about 16 houses. The above incident area, about $120 \mathrm{~m}$ there is a coral basin (lake karst) seasonally will hold water. In the rainy season the water will meet this basin and rises to a height of almost $2 \mathrm{~m}$, and a few minutes later the water had receded or disappeared from the basin. Allegedly this water moves in the soil following the direction of the slope, forming an underground river that is the hallmark of the region karts, the movement of water into the soil as a result of the fracture can be caused by an earthquake (study areas bypassed fault lines), causing the water to disappear quickly, a process of dissolving the dolomite limestone sinkhole formed, this process continues over time cause subsidence or soil collapse as happened in the study locations. This process must be preceded by fracturefracture the soil, trees sloping. Fault that occurred in this study storied locations, broken great height of $1.40 \mathrm{~m}$, followed by a fault towards the lower slope formed on the hole width of 20-100 m. As a result of Soil Creep and subsidence at the site of the study, about 16 homes were damaged, and until now the area can not be occupied. Trees and houses are still there, forming an angle of slope is 20 - 30o. Several examples of the type of landslide events were found in the study area as shown in Figure 7. 


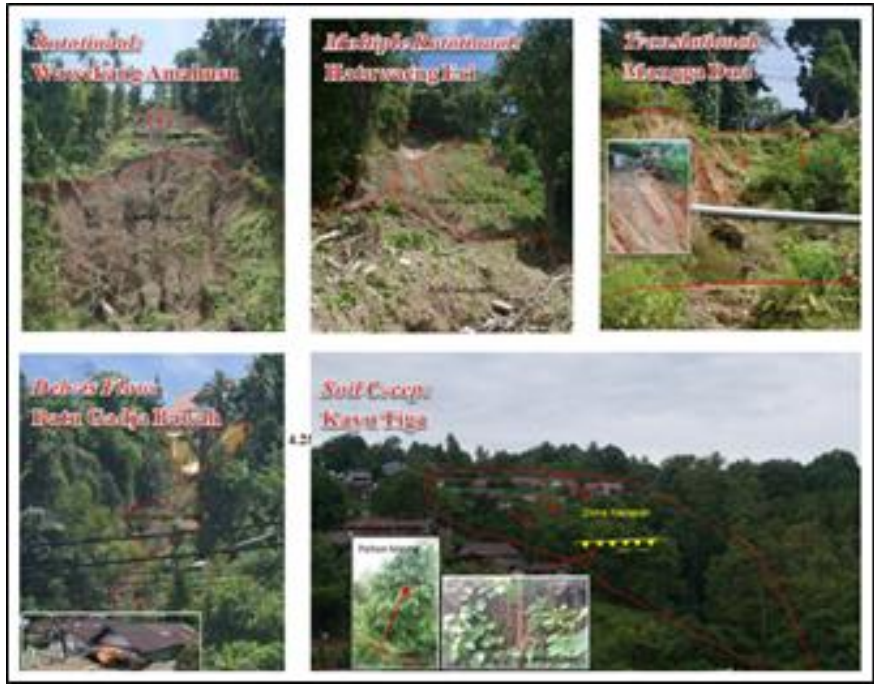

Figure 7. The 5 types of landslide that are founded in the Research Location

\section{CONCLUSIONS AND RECOMMENDATIONS Conclusion}

Using the methods of interpretation of landslide event base-location determination is then the best of the three methods where used the layered visual interpretation with a percentage of $90 \%$. With this method, it can be directly identified several locations of landslide event and its characteristic in the Leitimur Paninsula, Ambon Island. The digital imagery interpretation with NDVI has a $47 \%$ accuracy, thoroughness OBIA 45\%, Toposhape 47\%, the combination of NDVI-OBIA $47 \%$, and the combination of NDVI-OBIA-Toposhape $53 \%$ only for candidate of landslide in relation to actual deployment. From the interpretation of layered visual and field observations were obtained distribution locations of landslide event in Leitimur Paninsula, Ambon Island where it is located in the Village of Batu Gajah, Gardens Clove-Batu Merah, Passo, Soya, Hukurila, Manggadua, Hanging Rock, Amahusu, Nusanive Eri, and Silale with 5 types landslide were found there, namely soil rotational slide, soil creep, debris flow, earths slide and multiple rotational slide. The type of landslide, soil rotational slide is a type of spread of landslide that most of the study sites are located at 7 points or locations with a percentage of $38.9 \%$.

\section{Suggestion}

Based on the research that has been done, there are still some weaknesses that are expected to be improved in the future studies. For that there are some suggestions put forward here, namely:

1. It should be further investigated or reviewed the characteristic of landslide for various types with a high spatial resolution using satellite imagery which is updated after the landlsdie event to complete "Interpretation key" as generated in this study.
2. The use of the segmentation method to study the ladnsldie, OBIA must be tested using a highresolution satellite imagery in a narrow area and size of landslide, in a large field, which is expected to produce not only a candidate of landslide but to the landslide scene.

3. Toposhape that was built from SRTM DEM and using Idrisi needs to be examined further on its influence of landslide event in different locations, so it is expected to get a new theory which states that the type landslide, toposhape class A will discount that may not match the type of landslide $\mathrm{B}, \mathrm{C}$, and so on.

\section{REFERENCES}

Antonini, G., Ardizzone, F., Cacciano, M., Cardinali, M., Castellani, M., Galli, M., Guzzetti, F., Reichenbach, P., Salvati, P., 2002a. Rapporto conclusivo protocollo d'intesa fra la Regione dell'Umbria, Direzione Politiche Territoriali Ambiente e Infrastrutture, edil CNR IRPI di Perugia per l'acquisizione di nuove informazioni sui fenomeni franosi nella regione dell'Umbria, la realizzazione di una nuova carta inventario dei movimenti franosi e dei siti colpiti da dissesto, l'individuazione e la perimetrazione delle aree a rischio da frana di particolare rilevanza, e l'aggiornamento delle stime sull'incidenza dei fenomeni di dissesto sul tessuto insediativo, infrastrutturale e produttivo regionale. Unpublished report, May 2002, 140 pp., (in Italian).

Antonini, G., Ardizzone, F., Cardinali, M., Galli, M., Guzzetti, F., Reichenbach, P., 2002a. Surface deposits and landslide inventory map of the area affected by the 1997 Umbria-Marche earthquakes. Bollettino della Societa Geologica Italiana 121 (2), 843-853.

Barlow, J., Y. Martin., and S.E. Franklin., 2003. Detecting translational landslide scars using segmentation of Landsat ETM+ and DEM data in the northern Cascade Mountains, British Columbia. J. Remote Sensing, Vol. 29, No. 4. 
Cheng, K.S., Wei, C., Chang, S.C., 2004. Locating landslides using multi-temporal satellite images. Advances in Space Research 33 (3), 96 -301.

Danoedoro, P., 2012. Pengantar Penginderaan Jauh Digital. Penerbit ANDI.

Eastman. J.R., 2012. IDRISI Selva Tutorial. Manual Version 17. Clark University.

Ercanoglu. E., 2005. Landslide Suscepbtibility assessment of SE Bartin (West Black Sea Region, Turkey) by artificial neural network. https://hal.archivesouvertes.fr/hal-00299340. Submitted 5 Dec 2005. Akses 20 April 2015

Feryandi, F.T.H., 2011. Landslide Suscepbtibility assessment in Karanganyar Regency - Indonesia. Dissertation submitted in partial fulfiment of the requirements for the Degree of Master of Science in Geospatial Technologies. Institute for Geoinformatics (IFGI) Westfälische Wilhelms-Universität Münster Germany

Hansen A., 1984. Landslide Hazard Analysis. Slope Instability. In: Brunsden D, Prior DB (eds) Slope Instability. John Wiley \& Sons Ltd, New York.

Joyosuharto S., 1980. Interpretasi Foto Udara dan Pemetaan Geomorfologi. Materi kuliah (tidak dipublikasikan). Pusat Pendidikan Interpretasi Citra Penginderaan Jauh dan Survei Terpadu UGMBakosurtanal, Angkatan VI.

Laliberte, A. S., Rango, A., Havstad, K. M., Paris, J.F., Beck, R.F., McNelly, R., Gonzales, A. L., 2004. Object-oriented image analysis for mapping shrub encroachment from 1937 to 2003 in southern New Mexico. Remote Sensing of Environment

Lin, C.Y., Lin, W.T., Chou, W.C., 2002. Soil erosion prediction and sediment yield estimation: the Taiwan experience. Soil Tillage Res. 68, 143-152.

Liu, J.K., Wong, C.C., Huang, J.H., Yang, M.J., 2002. Landslideenhancement images for the study of torrentialrainfall landslides. 23rd Asian Conference on Remote Sensing, Kathmandu, Nepal. WWW page http://www.gisdevelopment.net/aars/acrs/ 2002/env/193.pdf.

Martha, T. R., Kerle, N., Jetten, V., van Westen, C. J., and Kumar, K. V.: Characterising spectral, spatial and morphometric properties of landslides for semiautomatic detection using object-oriented methods, Geomorphology, 116, 24-36, 2010.

Martha, T.R., Kerle, N., Jetten, V., van Westen, C., Vinod Kumar, K., 2010. Characterising spectral, spatial and morphometric properties of landslides for semi-automatic detection using object-oriented methods. Geomorphology 116, 24-36

Moine, M., Puissant, A., Malet, J.-P., 2009. Detection of landslides from aerial and satellite images with a semi-automatic method. Application to the Barcelonnette basin (Alpes-de-Haute-Provence, France). In: Malet, J.-P., Remaitre, A., Bogaard, T. (Eds.), Landslide Processes: From Geomorphological Mapping to Dynamic Modelling. CERG, Strasbourg, France, pp. 63-68.

Park, N.W., Chi, K.H., 2008. Quantitative assessment of landslide susceptibility using high-resolution remote sensing data and a generalized additive model. International Journal of Remote Sensing 29 (1),

Rib, H.T., Liang, T., 1978. Recognition and identification. In: Schuster, R.L., Krizek, R.J. (Eds.), Landslide Analysis and Control. : Transportation Research Board Special Report, 176. National Academy of Sciences, Washington, pp. 34-80.

Soejitno T., 1995. Teknik dan Aplikasi Geologi Foto. Penerbit PT. Rosda Jayaputra Jakarta.

Speight, J.G., 1977. Landform pattern description from aerial photographs. Photogrammetry 32, 161-182.

Stumpf, A., Kerle, N., 2011. Object-oriented mapping of landslides using Random Forest. Remote Sensing of Environment 115 (10), 2564-2577. doi:10.1016/ j.rse.2011.05.013.

Suharyadi., 2008. Penginderaan Jauh Dari Teknik ke Bidang Ilmu. Proceeding Filsafat Sains Geografi. Program Studi Pembangunan Wilayah. Fakultas Geografi Universitas Gadjah Mada.

Sutanto. 1994. Penginderaan Jauh Jilid I., Gadjam Mada University Press.

Tung Shih-Heng, Shih Ming-Hsiang and Sung Wen-Pei, 2013., Identification of the landslide using the satellite images and the digital image correlation method. Disaster Advances, Vol. 6 (4)

van Zuidam, R.A., 1985. Aerial photo-interpretation in terrain analysis and geomorphologic mapping. International Institute for Aerospace Survey and Earth Sciences (ITC). Smits Publishers, The Hague. $442 \mathrm{pp}$.

Wibowo T. S., R. Suharyadi., 2012. Aplikasi Object-Based Image Analysis (OBIA) untuk Deteksi Perubahan Penggunaan Lahan Menggunakan Citra ALOS AVNIR-2. Fakultas Geografi, Universitas Gadjah Mada.

Xiaojun Yang and Liding Chen, tahun 2009, Satellite Imagery for Lanslide Mapping In An Earthquake Struck Area: A Preliminary Study. Paper presented at the 24th International Cartographic Conference in Santiago, Chile, 15-21 November 2009.

Zaruba Q., and Mencl. V., 1969. Landslide and their control. Elsevier Pub. Co., Amstredam, 205 p. 